\title{
AN ANALYTICAL ASSESSMENT OF POULTRY INDUSTRY AND ADOPTION OF POTENTIAL VALUE ADDITION INTERVENTIONS IN BY-PRODUCT PROCESSING TO ENHANCE PROFITABILITY - IBADAN, OYO STATE, NIGERIA
}

\author{
Taofeek Ayodeji Ayo-Bello*, Osaige John Afodu, Tolulope Ogunleye, Lois \\ Ndubuisi-Ogbonna, Jesubukunmi Omoniyi
}

Department of Agriculture and Industrial Technology, Babcock University, Nigeria

*corresponding author: belloayodeji@ymail.com

\begin{abstract}
The need to diversify the Nigerian economy calls for value chain development of the agricultural and livestock sector. The main purpose of the study is to seek additional source of income for poultry producers through the processing of selected poultry by-products in the study area. A baseline study of poultry enterprises was carried out in Ibadan, Oyo State, Nigeria using a purposive sampling technique. A structured questionnaire was used in the collection of data and data collected was analyzed using descriptive statistics, gross margin analysis and Logit regression. The result showed and exhibited a gross margin ratio of $82.9 \%$ indicating profitability of enterprise. The regression result revealed that the adoption of poultry by-products processing was by different factors at different level of significance in organic fertilizer was influence. The study revealed that the respondents ranked high cost of machineries (25\%) as the major problem encountered by them. It was recommended that awareness should be intensified on management poultry by-products; encouragement of Public-Private Partnership (PPP), towards the provision of adequate infrastructure need for commercialization of poultry by-products processing in Nigeria.
\end{abstract}

Keywords: Agriculture, Income, Profitability, Poultry, By-Products, Processing, Management, Survey, Results

http://dx.doi.org/10.21776/ub.agrise.2021.021.3.3

Received 1 January 2021

Accepted 8 July 2021

Available online 31 July 2021

\section{INTRODUCTION}

Agriculture is an important contributor to the Nigerian economy, contributing to the Gross Domestic Product (GDP).It is a sector that provides employment, ensure food security, and contribute to poverty reduction, Agriculture is a key contributor to good health and improved nutrition. The sector contributions $22.93 \%$ to the GDP in 2017(NBS, 2017). Despites it contribution, the poultry sub-sector is the most commercialized (capitalized) of all the sub-sectors of the Nigerian agriculture (Ugwu, 2009). These contributions would have been more contributory if the byproducts of these outputs are processed and well utilized. With a population of over 200 million people in Nigeria, and a recommended minimum daily protein requirement of 35 grammes of protein per person per day (W.H.O), there is the need for an affordable source of protein to the entire populace, hence the need to effect development of the poultry value chain. Efficient processing and utilization of poultry by-products has direct impact on the enterprise, economy and environmental

CITATION: Ayo-Bello, T., A., Afodu, O., J., Ogunleye, T., Ndubuisi-Ogbonna, L., Omoniyi, L., (2021). An Analytical Assessment of Poultry Industry and Adoption of Potential Value Addition Interventions in By-Product Processing to Enhance Profitability - Ibadan, Oyo State, Nigeria, Agricultural Socio-Economics Journal, 21(3), 185-198 DOI: http://dx.doi.org/10.21776/ub.agrise.2021.021.3.3 
pollution status of the country. None or underutilization of by-products/waste not only leads to low returns on potential revenues but also leads to the additional cost for management of these products. Improper disposal of poultry by-products may create major aesthetic and catastrophic health problems. Besides pollution and hazard aspects, in many cases, poultry wastes have a potential for recycling raw materials or for conversion into useful products of higher value. Traditions, culture and religion are often important when a meat byproduct is being utilized for food.

With respect to poultry production wastes (manure and litter), these organic solids should be considered as both potential resources and environmental contaminats, depending on how they are processed and managed. The size of the slaughter facility can also determine the level of environmental and food safety practices and issues - again, the size issue is similar for poultry production facilities.

During treatment/processing of solid waste, it should be aimed at producing value-added sellable by-products, such as animal or aquaculture feed components, alternative energy source ( biogas production) and agricultural fertilizer. For small or backyard flock operations, slaughter probably going to produce very small quantities of solid wastes, and the management of these wastes should focus more on proper disposal and recycling (burial or composting) with respect to biosecurity and human health safety.

By-products such as gizzard, liver (edible use) feathers, blood and poultry droppings (inedible use) have good nutritive value. Therapeutic and pharmaceutical uses of by-product are also highlighted in this research. Majority of the waste in the poultry industry is produced during slaughtering and dressing. Slaughter house waste consists of the portion of a slaughtered animal that cannot be sold as meat or used in meat-products. Such waste includes feathers, bones, skin, contents of the gastro-intestinal tract, blood and other inedible viscera. Traditional markets for edible poultry by-products have gradually been dwindling due to health concerns. In response to these problems, there is the need to direct research efforts towards non-food uses. Other wastes are generated during the rearing process from point of lay (POL) to market size. Waste products from the poultry processing and egg production industries must be efficiently dealt with as the growth of these industries depend largely on waste management
With a consistent rise in cost of inputs, especially feed, and not necessarily a similar increase in price of poultry products, to maintain the profitability of the business and keep it lucrative, poultry farmers and poultry processors may have to look at alternative sources for additional income. There is the need to look into the value chain to provide additional source of income (value chain development). This can be sourced from the conversion of by-products seen as wastes to means of income generation.

An increase in the profitability of the poultry industry will go a long way in tackling the unemployment problem of the country. This is because additional streams of income will make the industry attractive, profit wise and more people, especially the youthful populace will be attracted to it. Also already existing small scale poultry businesses will have the opportunity for development and expansion.

The population of Nigerians is increasing which implies an increase in the demand for affordable protein sources which includes eggs (the cheapest available source of protein) and hence an increase in the demand for other poultry products, but likewise, there are huge problems militating against the poultry industry and one major problem is the increase in the cost of inputs, especially feed, cost of machinery and equipment, as well as cost of feed supplements, but this does not necessarily imply an increase in the price of poultry products, hence there is the need to focus on the value chain development of poultry processing to source for additional streams of income, and one key area is the value addition of by-products.

Over last decade, there has been an increasing cost of disposal of these by-products over an increasing poultry processing enterprise and this leads to loss in revenue. Asides this, waste disposal and by-product management in food processing industry has created/contributed to current environmental issues in terms of pollution, protection and sustainability (Russ and Pittroff 2004). The disposal of these wastes can pose problems especially in the areas of biological stability and the potential growth of pathogens as many types of waste material either already contain large numbers of microbes and/or will be altered quickly through microbial activity. If regulations concerning infections/diseases are not properly observed, then hygienically unacceptable condition can arise, e. g, maggots or molds. The breakdown of protein is always characterized by the evolution of strong odours. This process is referred to as 
rapid autoxidation which implies that waste with a high fat content is susceptible to oxidation, which leads to release of foul smelling fatty acids.

The poultry industry is a key aspect of the agricultural sector of the country, both to the producers (poultry farmers, Processors, wholesalers, distributors and everyone involved in the movement of poultry products from farm to fork) who derive their source of livelihood and in extension help to better the economy of the country and fight food insecurity, and also to the consumers who depend on poultry products as an affordable source of protein in their diet.

There is the need to look into the profitability of the business and seek for added sources of income to keep the industry attractive, to promote employment and to develop small scale industry. One of the key areas to do this is through the in depth understanding of workings of the byproducts of the industry.

\section{Study Objectives}

The broad objective of this study is to seek for added sources of income for poultry farmers through value chain development of their byproducts. The specific objectives are to:

- Describe the socioeconomic characteristics of poultry processors;

- Investigate the threat to the industry from not processing the by-products and to highlight the management strategies of the by-products;

- Estimate cost and returns of processing the by-products;
- Investigate the determinants of adoption of processing technology for poultry entrails;

- and investigate general challenges faced by the poultry entrepreneurs in processing poultry by-products

\section{RESEARCH METHODS}

\section{Methodology and Study Area Description}

The study was carried out in Ibadan. Ibadan is situated in south-western region of Nigeria. It is the capital of Oyo State, and is reputed to be the largest native city in Africa, south of the Sahara (Auta \& Morenikeji,2013). Ibadan had been the focal point of administration of the old Western Region, Nigeria since the times of the British colonial rule. It is located 78 miles inland from Lagos, and is a noticeable travel point between the coastal region and the areas to the north. The state has 33 Local Government Areas (LGAs) and its population is assessed to be $5,591,589$ (NPC, 2007). Oyo State is approximately $28,454 \mathrm{~km} 2$ of Nigeria's 923,218km2 land area. The primary occupants of the city are the Yoruba.

Enterprises in the area include are poultry, micro-agribusinesses such as flour-milling, furniture-production and other agricultural valuechain activities. There are a few cattle ranches, a dairy ranch as well as a business abattoir in Ibadan.

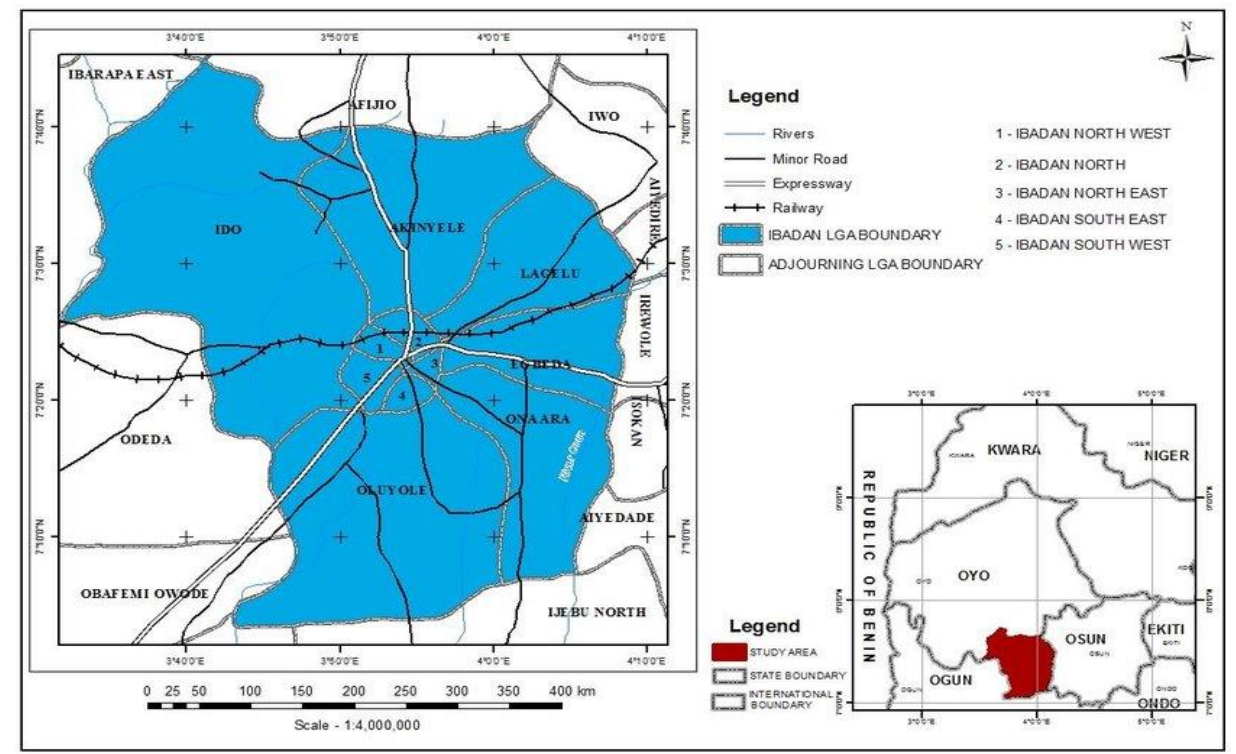

Figure 1: Map of Ibadan Metropolis Showing Local Government Areas (Inset: Oyo State Showing the Study Area) 
The study employed a purposive sampling procedure. And questionnaire administration and interview schedule were used for data collection. Twenty-five (25) respondents were sampled from the Ibadan North, Ibadan Southwest, and Ibadan east in Oyo State. The sample size was restricted to twenty (25) because of the limited population of processors in the study area, Oyo State.Information retrieved from the respondents were on the socioeconomic characteristics of the respondents viz age, level of education, years of experience, sex, religion of the farm owner, gender of the operator, stocking capacity on the farm, type of birds (e.g. broiler, cockerel), and system of production (e.g. Battery cage) etc.

Also, data was collected on the Awareness level of some best management strategies of byproducts utilization and general constraints faced in by-products processing and also on the Cost and returns of processing (poultry) by - products.

\section{Analytical Techniques}

Descriptive statistics was employed to describe the socioeconomic characteristics of the poultry farmers. Gross margin analysis was used to determine the profitability of processing the byproducts. Logit model was used to investigate the determinants of adoption of processing technology for poultry entrails.

\section{Logit model specification}

According to Gujarati (1988) the model

specification is as follows,

$$
\operatorname{Ln}\left(\mathrm{P}_{\mathrm{i}} /\left(1-\mathrm{P}_{\mathrm{i}}\right)\right)=\beta_{0}+\beta_{1} \mathrm{X}_{1}+\ldots .+\beta_{8} \mathrm{X}_{8}+\mathrm{e}_{\mathrm{I}},
$$

Where

$P_{i}=$ probability of adoption, $\beta_{1}=$ coefficients, $X_{1}=$ independent variables, and ei $=$ error term. The dependent variables are the natural $\log$ of the probability of adopting poultry by-product $\left(\mathrm{P}_{\mathrm{i}}\right)$ divided by the probability of not adopting $\left(1-\mathrm{P}_{\mathrm{i}}\right)$. The following independent variables were hypothesized to influence adopters positively (+), or negatively (-).these independent variables are described as follows:

$$
\begin{aligned}
& \mathrm{Y}=\mathrm{f}(\text { Socioeconomic characteristics } \mathrm{X}) \\
& \text { Where; } \\
& \mathrm{Y}=1, \text { if adopted } \\
& \mathrm{Y}=0 \text {, if not adopted. } \\
& \mathrm{X}=\text { Matrix of independent variables viz: } \\
& \text { - Age of the farm }\left(\mathrm{X}_{1}\right)
\end{aligned}
$$

- Sex of the farm owner/respondent $\left(\mathrm{X}_{2}\right)$

- $\quad$ Age of the respondent $\left(\mathrm{X}_{3}\right)$

- Religion of respondent $\left(\mathrm{X}_{4}\right)$

- Educational level $\left(\mathrm{X}_{5}\right)$

- Years of experience $\left(\mathrm{X}_{6}\right)$

- $\quad$ Stocking capacity $\left(\mathrm{X}_{7}\right)$

- Poultry system used $\left(\mathrm{X}_{8}\right)$

- Awareness $\left(\mathrm{X}_{9}\right)$

$\beta$ are parameters to be estimated

$\mathrm{u}=$ Stochastic disturbance

\section{Gross Margin Analysis}

Gross margin (GM) is gross farm income (GFI) less total variable cost (TVC).

POULTRY GROSS MARGIN $($ PGM $)=$

Poultry by-product Total Revenue (PGR) - Poultry by-product processing Total Variable Costs (PTVC)

Gross Margin ratio $=\frac{\text { Gross Margin }}{\text { Total revenue }} \%$

Gross Margin (GM) analysis was employed to determine the profitability of processing predetermined poultry by products and then to make recommendations as to the profitability of each by-products to both the processors and nonprocessors.

The gross margin ratio is to see what portion of the total revenue comes into the enterprise as income. Hence, it is a performance ratio (Canadian Agrifood Policy Institute, 2009). The benchmark of profitability is $65 \%$ and anything from this above is deemed profitable, but anything less than $65 \%$ is deemed non-

\section{RESULTS AND DISCUSSION}

The results shown in table 1 indicate that out of 25 respondents $72.0 \%$ of the owners of the processing facilities/processor are male while the remaining $28.0 \%$ are female. This implies that higher proportion of the poultry processing in the study area is carried out by men. The results also indicate that no respondent is below 20 years, while $12.0 \%$ of the respondents fall between 21-30 years, and majority of $76.0 \%$ fall between the ages of 31 and 50 years and the last $12 \%$ were above 51 years. This implies that majority of the processors are young and vibrant and in their economically active age.

The distribution of respondents by years of experience as shown in Table 1 indicate that $36 \%$ of the respondents had working experience below 
10 years in the processing industry, $48 \%$ had working experience of 10-20 years, $16 \%$ had working experience of 21-50 years and no respondent had above 50 years' experience, meaning that all the processors in the study area, all started their exploration into the business within the past 50 years.

Based on the results as shown in Table 1, distribution of the respondents by number of birds raised shows that $20 \%$ of the processors have poultry farms where they raise between $4000-5000$ birds, $52 \%$ have a poultry population of 5,00010,000 birds, $20 \%$ raise between 10,000-15,000 birds and only $8 \%$ of the processors have above 15 , 000 birds. This implies that the processing business is only profitable when dealing with a commercial amount/ when dealing with large scale farms.

Table 1: Respondents Distribution by Socio-economic Characteristics

\begin{tabular}{|c|c|c|c|}
\hline \multicolumn{2}{|l|}{ Variable } & \multirow{2}{*}{$\begin{array}{l}\text { Frequency } \\
18\end{array}$} & \multirow{2}{*}{$\begin{array}{l}\text { Percentage } \\
72.0\end{array}$} \\
\hline Sex & Male & & \\
\hline & Female & 7 & 28.0 \\
\hline \multirow[t]{4}{*}{ Age of the farmer (years) } & $<20$ & 0 & 0.0 \\
\hline & $21-30$ & 3 & 12.0 \\
\hline & $31-50$ & 19 & 76.0 \\
\hline & Above 51 & 3 & 12.0 \\
\hline \multirow[t]{4}{*}{ Years of experience } & $<10$ & 9 & 36.0 \\
\hline & $10-20$ & 12 & 48.0 \\
\hline & $21-50$ & 4 & 16.0 \\
\hline & Above 50 & 0 & 0.0 \\
\hline \multirow[t]{4}{*}{ Number of birds raised } & $500-5000$ & 5 & 20.0 \\
\hline & $5000-10,000$ & 13 & 52.0 \\
\hline & $10,000-15,000$ & 5 & 20.0 \\
\hline & $>15,000$ & 2 & 8.0 \\
\hline \multirow[t]{4}{*}{ Education level } & No formal education & 0 & 0.0 \\
\hline & Primary education & 0 & 0.0 \\
\hline & Secondary education & 2 & 8.0 \\
\hline & Post-secondary education & 23 & 92.0 \\
\hline \multirow[t]{4}{*}{ Age of the farm (years) } & $1-10$ & 9 & 36.0 \\
\hline & $11-20$ & 11 & 44.0 \\
\hline & $21-40$ & 2 & 8.0 \\
\hline & $>40$ & 3 & 12.0 \\
\hline \multirow[t]{5}{*}{ Poultry system used } & Battery cage & 7 & 28.0 \\
\hline & Deep litter & 8 & 32.0 \\
\hline & Both & 6 & 24.0 \\
\hline & Not applicable & 4 & 16.0 \\
\hline & Total & 25 & 100 \\
\hline
\end{tabular}


The result on the distribution of respondents by level of education shows that $8 \%$ of the respondents had only secondary education, and the remaining $92 \%$ had post-secondary or tertiary education. This implies that the processing industry is dominated by well-read individuals that are literates. Also the distribution of the respondents by Age of the enterprise/ farm on Table 1 reveals that $36 \%$ of the respondents had their farms to have been established within the past 10 years, $44 \%$ had been established between 11-20 years, $8 \%$ had been in existence between 21-40 years, and 12\% had been established for over 40 years. The modal class for age of enterprise is within the ages of $11-20$ years; hence, the enterprise has seen the highest influx of players within the past 20 years.

Distribution of respondents according to the housing system of poultry birds on Table 1 shows that $28 \%$ of the respondents made use of battery cages on their farms, $32 \%$ made use of deep litter system and $24 \%$ used both battery cage and deep litter system. Some I6\% did not make use of either and this was for the sole reason that they are only processing enterprises and are not involved in the raising of birds, but rather buy birds from poultry farmers or act as contractors for poultry farmers who want to process their birds.

\section{Management Strategies of Poultry Droppings}

Table 2 shows that $28 \%$ of the processors in the study area managed their poultry droppings by selling them off. They either dried and sold them off as compost or they sold them off to fish farmers who use it as feed for their fishery in producing maggot otherwise known as 'Mag-meal'. Majority of the respondents noted that their buyers were Hausa men who came and collected the droppings from their farms at zero cost. They came with their own sacks and collected the droppings. Some $32 \%$ of the respondents disposed their droppings in dumpsites, $16 \%$ of the processors channeled their droppings into stream, and $8 \%$ gave it out to whoever needed it at no cost at all or as free gift. The last $16 \%$ of the respondents were involved only in processing and did not have farms, they only engaged in the processing of birds for farmers or customers who want to process their birds.

\section{Management Strategies for Cracked Eggs}

Table 2 shows that $56 \%$ of the respondents sell off their cracked eggs. The cracked eggs incurred no storage cost or input cost; all which is involved is that they are kept in a clean place clear from flies and other contaminants. The cracked eggs are graded according to the nature of the cracks. Extremely cracked eggs are sold to fish farmers who eventually pelletize it into the fish feeds, and these are sold at about $\$ 100$ per crate. Others that are of manageable cracks are sold for about $\$ 200$ less the original price of the crate to customers including those involved in confectionaries production (4\% of respondents were involved in this). Some $4 \%$ disposed theirs in dumpsites and the last $20 \%$ gave it out as free gifts.

\section{Management Strategies for Feathers}

Table 2 shows that $12 \%$ of the respondents utilize their feathers as fish feed. They are used as floaters to make the feed float on the water surface and also, they are good source of protein to the fish. Some $44 \%$ of the respondents disposed the feathers in dumpsite. About $32 \%$ of the respondents gave the feathers out as free gift. Majority of the respondents said they made it mandatory for all the customers of their legs, head and other entrails to compulsory carry the feathers, this was a convenient and affordable medium of disposal.

\section{Management Strategies for Mortalities}

In the study area which is Ibadan, mortalities are locally referred to as Opiro or Morta. Some $12 \%$ of the respondents sold their mortalities at a rate of 150 per bird on an average, $20 \%$ of the respondents made use of the mortalities for fish feed, $32 \%$ disposed of their mortalities in dumpsites, $20 \%$ of the processors disposed them by burying them underneath the ground, $16 \%$ of the respondents utilized theirs as either dog feed or sold it to those who used it as dog feeds.

\section{Management Strategies for legs/ feet}

About $64 \%$ of the respondents sold this particular by-product. A point worthy of note is that majority of the respondents said that most of the buyers who came to buy in bulk came from the south-south region of Nigeria (Port-Harcourt, Warri) and information gotten was that it is a 
delicacy in the region. The remaining $36 \%$ of respondents disposed theirs by dumping at sites.

Heads

This is similar to the legs/ feet. Some $64 \%$ of the respondents sold this particular by-product. A point worthy of note is that majority of the respondents said that most of the buyers who came to buy in bulk came from the south-south region of Nigeria (Port-Harcourt, Warri) and information gotten was that it is a delicacy in the region. The remaining $36 \%$ disposed theirs by dumping at sites.

\section{Management Strategies for Poultry Wastewater} About $48 \%$ of the sampled population channeled their waste water into nearby streams and $52 \%$ channeled theirs into their septic tanks however none of the respondent(processors) adopted the Phyto remediation technology this may be due to lack of knowledge or awareness on the Phyto remediation processes. Thus the waste water is neither used as a source of income nor does it incur any cost of utilization (Except probably, the initial cost of constructing a septic tank).

Table 2: Respondents Distribution by Management strategies of the by-products

\begin{tabular}{|c|c|c|}
\hline Management Strategies & Frequency & Percentage \\
\hline \multicolumn{3}{|l|}{ Poultry Droppings } \\
\hline Sales & 7 & 28.0 \\
\hline Dumpsite & 8 & 32.0 \\
\hline Channel to Stream & 4 & 16.0 \\
\hline Free gift & 2 & 8.0 \\
\hline Not applicable & 4 & 16.0 \\
\hline \multicolumn{3}{|l|}{ Cracked eggs } \\
\hline Sales & 14 & 56.0 \\
\hline Dumpsite & 1 & 4.0 \\
\hline Free gift & 5 & 20.0 \\
\hline Confectionaries \& Cakes & 1 & 4.0 \\
\hline N/A & 4 & 16.0 \\
\hline \multicolumn{3}{|l|}{ Feathers } \\
\hline Fish feed & 3 & 12.0 \\
\hline Dumpsite & 11 & 44.0 \\
\hline Free gift & 8 & 32.0 \\
\hline N/A & 3 & 12.0 \\
\hline \multicolumn{3}{|l|}{ Blood } \\
\hline Fish feed & 2 & 8.0 \\
\hline Channel to stream & 2 & 8.0 \\
\hline Septic tank & 13 & 52.0 \\
\hline N/A & 8 & 32.0 \\
\hline \multicolumn{3}{|l|}{ Mortalities } \\
\hline Sales & 3 & 12.0 \\
\hline Fish feed & 5 & 20.0 \\
\hline Dumpsite & 8 & 32.0 \\
\hline Bury & 5 & 20.0 \\
\hline Dog feed & 4 & 16.0 \\
\hline \multicolumn{3}{|l|}{ Legs/feet } \\
\hline Sales & 16 & 64.0 \\
\hline N/A & 9 & 36.0 \\
\hline \multicolumn{3}{|l|}{ Heads } \\
\hline Sales & 16 & 64.0 \\
\hline N/A & 9 & 36.0 \\
\hline \multicolumn{3}{|l|}{ Waste water } \\
\hline Channel to Stream & 12 & 48.0 \\
\hline Septic tank & 13 & 52.0 \\
\hline Phyto remediation processes & 0 & 0.0 \\
\hline Total & 25 & 100 \\
\hline
\end{tabular}

Source: Field Survey, 2019. 
Table 3: Estimated Cost and returns of by-products utilization (per enterprise)

\begin{tabular}{llll}
\hline Respondents & Total Revenue (\#) & Total Variable cost (\#) & Gross Margin (\#) \\
\hline 1 & 239250 & 32000 & 207,250 \\
2 & 1121050 & 230000 & 891,050 \\
3 & 271100 & 64000 & 207,100 \\
4 & 369850 & 60000 & 309,850 \\
5 & 266050 & 52000 & 214,050 \\
6 & 248400 & 42400 & 206,000 \\
7 & 322500 & 44800 & 277,700 \\
8 & 537900 & 92000 & 445,900 \\
9 & 263800 & 43200 & 220,600 \\
10 & 352600 & 51200 & 301,400 \\
11 & 151500 & 25600 & 125,900 \\
12 & 105600 & 23200 & 82,400 \\
13 & 1450600 & 240000 & $1,210,600$ \\
14 & 121250 & 20000 & 101,250 \\
15 & 132360 & 23600 & 108,760 \\
16 & 126800 & 22500 & 104,300 \\
17 & 105400 & 25200 & 130,600 \\
18 & 104450 & 24300 & 128,750 \\
19 & 360500 & 40800 & 319,700 \\
20 & 386850 & 43400 & 343,450 \\
21 & 315050 & 52800 & 262,250 \\
22 & 1050070 & 160000 & 890,070 \\
23 & 302550 & 44400 & 258,150 \\
24 & 670830 & 144000 & 526,830 \\
25 & 283750 & 51200 & 232,550 \\
$\Sigma$ & $\mathbf{9 , 7 0 9 , 5 6 0}$ & $\mathbf{1 , 6 5 2 , 6 0 0}$ & $\mathbf{8 , 0 5 6 , 9 6 0}$ \\
\hline
\end{tabular}

Source: Field Survey, 2019

\section{Gross Margin Analysis of Processing by- Products}

Table 3 shows the estimated cost and returns of processing by-products in the study area Revenue and cost were done on individual basis i.e. Gross margin was computed on enterprise by enterprise basis. Revenue from each enterprise was collated from sales of poultry droppings, cracks/ cracked eggs, feathers, legs/feet, heads, and mortalities. Cost considered were variable costs which comprised cost of labour, cost of packaging materials, energy used etc. Among the cost components, cost of labour had the largest share of total variable cost.

From table 4, estimated revenue and cost were $\$ 9,709,560$ and $\$ 1,652,600$ respectively. Hence the gross margin was $\$ 8,056,960$. The average gross margin was estimated to be $322,278.40$, average total revenue was $388,382.4$. Hence, the gross margin ratio was $82.9 \%$. This shows a very high percentage when compared to the benchmark of $65 \%$, which is the measure of profitability and financial performance of an enterprise (CAPI, 2009). This measure of performance indicates that processing poultry byproducts in the study area is viable and profitable.

Table 4: Summary of Cost and returns (estimate) of processing poultry by-products in Ibadan, Oyo State

\begin{tabular}{ll}
\hline Variable & Amount in Naira ( $)$ \\
\hline Total Value of revenue for & $9,709,560$ \\
25 processors & \\
Average of total revenue & $388,382.4$ \\
Total variable cost for the & $1,652,600$ \\
25 processors & \\
Total Gross Margin for the & $8,056,960$ \\
25 processors & \\
Average of gross margin & $322,278.4$ \\
Gross Margin Ratio (\%) & $82.9 \%$ \\
\hline Source: Field Survey 2019.
\end{tabular}

Determinants of By-Products Processing / Utilization in the Study area Using Logit Model It is important to know what factors determine the adoption of the processing of the poultry by-products. These were thus undertaken for the various byproducts as adoption of processing the by-products vary among the 
respondents. The results of our finding are thus given in Table 5.

Table 5 shows the result of the Logit regression analysis for the determinants of adoption of poultry by-products in the study area.

The regression result reveals that for the adoption of poultry droppings processing, age of respondents $\left(\mathrm{X}_{3}\right)$, years of experience $\left(\mathrm{X}_{6}\right)$, stocking capacity $\left(\mathrm{X}_{7}\right)$ and awareness $\left(\mathrm{X}_{9}\right)$ had positive and significant relationships with adoption. And the result showed that at $(\mathrm{p} \leq 0.5)$, an increase in age of respondents $\left(\mathrm{X}_{3}\right)$, years of experience $\left(\mathrm{X}_{6}\right)$, stocking capacity $\left(\mathrm{X}_{7}\right)$ will increase the adoption of poultry droppings processing while at $(p \leq 0.10)$ increase in awareness $\left(X_{9}\right)$ will increase the adoption of poultry droppings processing. Suggesting that total adoption will increase significantly if these factors are increased.

Table 5 also revealed the result for the regression analysis of the determinants of adoption of mortalities processing in the study area and its findings showed that age of respondents $\left(\mathrm{X}_{3}\right)$, and awareness $\left(\mathrm{X}_{9}\right)$ had positive significant relationships with adoption. And the result showed that at $(p \leq 0.5)$ increase in age of respondents $\left(X_{3}\right)$, and awareness $\left(\mathrm{X}_{9}\right)$ will increase their adoption for mortalities processing. This suggests that total adoption will increase significantly if these factors are increased.

Table 5 shows the result of the Logit regression analysis for the determinants of adoption of poultry by-products in the study area.

The regression result reveals that for the adoption of poultry droppings processing, age of respondents $\left(\mathrm{X}_{3}\right)$, years of experience $\left(\mathrm{X}_{6}\right)$, stocking capacity $\left(\mathrm{X}_{7}\right)$ and awareness $\left(\mathrm{X}_{9}\right)$ had positive and significant relationships with adoption. And the result showed that at ( $\mathrm{p} \leq 0.5)$, an increase in age of respondents $\left(\mathrm{X}_{3}\right)$, years of experience $\left(\mathrm{X}_{6}\right)$, stocking capacity $\left(\mathrm{X}_{7}\right)$ will increase the adoption of poultry droppings processing while at $(\mathrm{p} \leq 0.10)$ increase in awareness $\left(\mathrm{X}_{9}\right)$ will increase the adoption of poultry droppings processing. Suggesting that total adoption will increase significantly if these factors are increased.

Table 5 also revealed the result for the regression analysis of the determinants of adoption of mortalities processing in the study area and its findings showed that age of respondents $\left(\mathrm{X}_{3}\right)$, and awareness $\left(\mathrm{X}_{9}\right)$ had positive significant relationships with adoption. And the result showed that at $(p \leq 0.5)$ increase in age of respondents $\left(X_{3}\right)$, and awareness $\left(\mathrm{X}_{9}\right)$ will increase their adoption for mortalities processing. This suggests that total adoption will increase significantly if these factors are increased.

Table 5 also reveals the result of the regression analysis for the determinants of adoption of cracked eggs processing in the study area. and The findings shows that age of the farm $\left(\mathrm{X}_{1}\right)$, age of respondents $\left(\mathrm{X}_{3}\right)$, level of education $\left(\mathrm{X}_{5}\right)$, years of experience $\left(\mathrm{X}_{6}\right)$, and poultry system used $\left(\mathrm{X}_{8}\right)$ had positive and significant relationships with adoption all at $(p \leq 0.5)$. This suggests that total adoption will increase significantly if these factors are increased.

Table 5 shows the result of the regression analysis of the determinants of adoption of feathers processing in the study area. The result of the analysis shows that years of experience $\left(\mathrm{X}_{6}\right)$, stocking capacity $\left(\mathrm{X}_{7}\right)$ and awareness $\left(\mathrm{X}_{9}\right)$ had positive and significant relationships with adoption all at ( $\mathrm{p} \leq 0.5)$. This suggests that total adoption will increase significantly if these factors are increased.

Table 5 revealed the result of the regression analysis on the determinants of adoption of processing heads and legs in the study area. The result of the analysis shows that years of experience $\left(\mathrm{X}_{6}\right)$, stocking capacity $\left(\mathrm{X}_{7}\right)$ and awareness $\left(\mathrm{X}_{9}\right)$ had positive and significant relationships with adoption at $(\mathrm{p} \leq 0.5)$ for stocking capacity $\left(\mathrm{X}_{7}\right)$ and awareness $\left(X_{9}\right)$ and $(p \leq 0.10)$ for years of experience $\left(\mathrm{X}_{6}\right)$. This suggests that total adoption will increase significantly if these factors are increased.

\section{General Challenges Faced by Poultry Processors in By-Products Processing}

The processors of poultry by-products face various challenges. Prominent amongst the challenges is the cost of machineries required for the processing.

The analysis revealed that the respondents ranked high cost of machineries as the major problem encountered by them. Difficulty in accessing capital and finance to venture into processing the by -products on a commercial scale was ranked second highest constraint by the respondents. Poor electricity and inadequate storage facilities was ranked third by the respondents. 
Table 5: Regression Result for The Determinants of Processing/ Utilization of Poultry By-Products

\begin{tabular}{|c|c|c|c|c|c|c|c|c|c|c|}
\hline \multirow{2}{*}{$\begin{array}{l}\text { Variable } \\
\text { Variable }\end{array}$} & \multicolumn{2}{|c|}{ poultry droppings } & \multicolumn{2}{|c|}{ utilizing mortalities } & \multicolumn{2}{|c|}{ utilizing cracked eggs/ cracks } & \multicolumn{2}{|c|}{ utilizing feathers } & \multicolumn{2}{|c|}{ utilizing Heads and Legs } \\
\hline & t-value & Coefficient & t-value & Coefficient & t-value & Coefficient & t-value & Coefficient & t-value & Coefficient \\
\hline Age of the farm $\left(\mathrm{X}_{1}\right)$ & -1.833 & -0.562 & -2.575 & -0.194 & 2.174 & $0.044 * *$ & -0.301 & -0.812 & -0.870 & -0.626 \\
\hline $\operatorname{Sex}\left(X_{2}\right)$ & 0.311 & 0.656 & -0.983 & -0.968 & -0.959 & -0.351 & -0.047 & -0.085 & 0.302 & 0.856 \\
\hline Age of respondents $\left(\mathrm{X}_{3}\right)$ & 2.914 & $0.015 * *$ & 2.401 & $0.042 * *$ & 2.509 & $0.023 * *$ & -1.483 & -0.218 & -0.390 & -0.701 \\
\hline Religion $\left(\mathrm{X}_{4}\right)$ & 2.422 & 0.241 & 0.302 & 0.781 & 0.505 & 0.620 & -1.935 & -0.063 & 0.302 & 0.767 \\
\hline Level of education $\left(\mathrm{X}_{5}\right)$ & -0.154 & -0.461 & 0.482 & 0.358 & 2.491 & $0.023^{* *}$ & -0.990 & -0.096 & -1.541 & -0.729 \\
\hline Years of experience $\left(\mathrm{X}_{6}\right)$ & 2.189 & $0.011 * *$ & -0.757 & -0.052 & 2.854 & $0.011 * *$ & 2.969 & $0.019 * *$ & 1.204 & $0.022 * * *$ \\
\hline Stocking capacity $\left(\mathrm{X}_{7}\right)$ & 2.044 & $0.029 * *$ & 0.863 & 0.141 & -0.075 & -0.941 & 2.353 & $0.047 * *$ & 2.245 & $0.036 * *$ \\
\hline Poultry system used $\left(\mathrm{X}_{8}\right)$ & -0.396 & -0.249 & -0.053 & -0.401 & 2.718 & $0.015^{* *}$ & -1.614 & -0.705 & -1.293 & -0.214 \\
\hline Awareness $\left(\mathrm{X}_{9}\right)$ & 1.522 & $0.160 * * *$ & 2.941 & $0.024 * *$ & 0.596 & & 2.862 & $0.037 * *$ & 2.935 & $0.038 * *$ \\
\hline Constant & 1.98 & $0.231 * *$ & 2.89 & $0.037 * *$ & 2.174 & $0.044 * *$ & 3.49 & 0.026 & 1.99 & 0.032 \\
\hline
\end{tabular}

Source: Field survey 2019

*Means significant at $1 \%$ level, $* *$ Means significant at $5 \%$ level, $* * *$ Means significant at $10 \%$ level 
Due to the recent changes in the climate, there have been inconsistencies and this affects the processing of some of these by-products, as some of them e.g. feathers are still dried by sun drying, there has been slight difficulty in doing this due to the climate change. Hence, a weather / climatic inconsistency were ranked fourth by the respondents.

Table 6: Respondents Distribution by Processing Challenges

\begin{tabular}{|c|c|c|}
\hline $\begin{array}{l}\text { Constraints/ } \\
\text { Challenges }\end{array}$ & Percentage & Ranking \\
\hline $\begin{array}{l}\text { High cost of } \\
\text { Machinery }\end{array}$ & $25 \%$ & $1^{\text {st }}$ \\
\hline $\begin{array}{l}\text { Low Capital and } \\
\text { Finance }\end{array}$ & $18 \%$ & $2^{\text {nd }}$ \\
\hline $\begin{array}{l}\text { Inadequate Storage } \\
\text { facilities }\end{array}$ & $15 \%$ & $3^{\text {rd }}$ \\
\hline $\begin{array}{l}\text { Weather/Climatic } \\
\text { inconsistencies }\end{array}$ & $13 \%$ & $4^{\text {th }}$ \\
\hline $\begin{array}{ll}\begin{array}{l}\text { Demand } \\
\text { processed }\end{array} & \text { for } \\
\text { products } & \text { by- }\end{array}$ & $12 \%$ & $5^{\text {th }}$ \\
\hline $\begin{array}{l}\text { Government Health } \\
\text { Agencies bottleneck }\end{array}$ & $9 \%$ & $6^{\text {th }}$ \\
\hline $\begin{array}{l}\text { Lack of proper } \\
\text { marketing channel for } \\
\text { processed } \\
\text { products }\end{array}$ & $8 \%$ & $7^{\text {th }}$ \\
\hline Total & $100 \%$ & \\
\hline
\end{tabular}

Source: Field Survey, 2019.

Low demand for the processed byproducts was mentioned by $12 \%$ of the respondents and ranked fifth. This showed that it is not a high ranking constraint, as demand is actually high for most of the processed by-products. Also, $9 \%$ of the respondents reported bottlenecks of government health agencies as a constraint, thus ranking 6th. This is not a widespread problem only when it entails using some of these processed by-products as food or for direct human consumption or when they are used as feed or a composite of feed for animal consumption. Lack of proper marketing channel for the processed by products was ranked as the least important constraint facing the byproducts processing entrepreneurs.

\section{CONCLUSIONS AND RECOMMENDATIONS}

\section{Conclusion}

From this study, it can be ascertained that there are opportunities for commercialization of the poultry by-products processing enterprise in Oyo state and Nigeria in general, notwithstanding the various identified constraints. This study is particularly important to the average farmer because it can help expand his/her enterprise through a proper handling and management of byproducts as an additional source of income other than just waste products meant for disposal. The gross margin ratio was $82.9 \%$ which shows successful profitability of enterprise.

\section{Recommendation}

In order to promote the profitability and also enhance the adoption of poultry by-products processing, the following recommendations are considered necessary:

Public-private partnership (PPP) should be fostered so as to the commercialization of the poultry/ poultry by-products processing enterprise in Nigeria. By working closely with the processors, there can be a good flow of information from the government health and safety agencies on stipulated criteria for safety standards, also the government can help finance these processors and under this arrangement the enabling environment will be created for effective participation of the private sector in by-products generation, processing, storage and marketing.

Nature based Treatment of poultry wastewater such as Phyto-remediation should be encouraged to compliment for high cost of disposal, treating and processing of poultry waste due to Lack of and/or epileptic power supply in agricultural production and commercialization in Nigeria.

Government should tackle the problem of rural access roads to enhance rapid rural entrepreneurship and industrialization particularly on the poultry by-product processing in Nigeria.

Finally, INGOs and NGOs should help farmers and processors on a sustained awareness strategies/behavioral change communication strategies that will help in enhancing poultry/ poultry by-products processing enterprise in Nigeria.

\section{BIBLIOGRAPHY}

Adeoye P.A, Hasfalina C.M, Mohammed A.S, Thamer A.M, Akinbile C.O (2012). Poultry waste effect on shallow groundwater quality in selected farms in Minna, North-central Nigeria. ProcIntConfAgric Food Eng for life University Putra, Malaysia; 554-565. 
Akanni K. A, Benson O. B (2014). Poultry waste management strategies And Environmental Implications on human health in Ogun State of Nigeria; Advances in Economics and Business 2(4): 164-171.

Alao, J.A. (1975), "Characteristics of Farmers Who Adopt Agricultural Innovation in Nigeria" Journal of Rural Economy and Development. 9, (1): Pp 18-25.

Auta, T. I. M. O. T. H. Y., \& Morenikeji, O. A. (2013). Heavy metal concentrations around a hospital incinerator and a municipal dumpsite in Ibadan City, South-West Nigeria. Journal of Applied Sciences and Environmental Management, 17(3), 419-422.

Bowman, A. Mueller, K. \& Smith, M. (2000).Increased animal waste production from concentrated animal feeding operations: potential implications for public and environmental health. Occasional Paper Series, No, 2. Omaha, USA, Nebraska Centre for Rural Health Research.

Canadian Agrifood Policy Institute (CAPI) (2009). Measuring farm productivity and financial performance. Report 2009: 19-21.

Carr, L. (1994). Why and how compost works. In Proceedings of the National Poultry Waste Management Symposium, Athens, Georgia, USA.31 Oct-2 Nov. 1994, pp. 104108.Proceedings 1994 National Poultry Waste Management Symposium.P. H. Patterson and J. P. Blake, Ed. National Poultry Waste Management Symposium Committee.Auburn University Printing Services, Auburn University, AL 36849.ISBN 0-9627682-6-4.

Charles Michael Williams (2009). Poultry waste management in developing countries, FAO review.

Clark, S., Rylander, R. \& Larsson, L. (1983).Airborne bacteria, endotoxin and fungi in dust in poultry and swine confinement buildings. Am. Indus, Hygiene Assoc. J, 44(7): 537-541.

D. Thyagarajan, M. Barathi, R. Sakthivadivu (2013). Scope of Poultry Waste Utilization; IOSR Journal of Agriculture and Veterinary Science (IOSR-JAVS) 6: 29-35.

Daniel S. Ugwu (2009). Baseline Study of Small and Medium Scale Poultry Production in Enugu and Lagos States of Nigeria, World Journal of Agricultural Sciences 5 (1): 27-33, 2009.

FAO. (2006). Livestock's Long Shadow environmental issues and options, by $\mathrm{H}$.
Steinfeld, P. Gerber, T. Wassenaar, V. Castel, M. Rosales and C. de Haan. Section 3.3 on Livestock in the nitrogen cycle.ftp://ftp.fao.org/docrep/fao/010/a0701e/ a0701e00.pdf

FAO. (2008). Poultry in the 21st century: avian influenza and beyond. Proceedings of the International Poultry Conference, Bangkok, 5 -7 Nov.

FAO /CMS. 1996. Biogas technology: a training manual for extension

Gundersen, P. 1992. Mass balance approaches for establishing critical loads for nitrogen in terrestrial ecosystems. In Proceedings of a Workshop in Lockenberg, Sweden, pp. 56-81. Copenhagen, Nordic Council of Ministers Report.

Manyong, V.M., A. Ikpi, J.K. Olayemi, S.A. Yusuf, B.T. Omonona, V. Okoruwa and F.S. Idachaba, (2005). Agriculture in Nigeria: Identifying opportunities for increased commercialization and investments. IITA Ibadan, Nigeria.pp: 159

McCaskey, T. (1995). Feeding poultry litter as an alternative waste management strategy. In K. Steele, ed. Animal waste and the land water interface pp. 475-484

Meyn Poultry Processing Solution (2004), Environmental health and safety guidelines for poultry processing; World bank group; 10 $-11$

NBS (2017)National Bureau of Statistics, Nigerian Gross Domestic Product Report Q4 2017.

NPC (2007).National Population Commission. Bulletins on Population Census figures

Ojolo SJ, Oke SA, Animasahun K, Adesuyi BK. (2007) Utilization of poultry, cow and kitchen wastes for biogas production: A comparative analysis. Iranian J Environmental Health Science Eng; 4(4):223-228.

P. A. Adeoye, C. M. Hasfalina, M. S. M. Amin, A. M. Thamer, C. O. Akinbile (2014). Environmental implication of poultry waste generation and management technique in Minna, semi-arid region of Nigeria; Annual Research \& Review in Biology 4(10): 16691681.

Poultry Science Association. (2009) Research demonstrates effectiveness of trees and shrubs in reducing odours, dust and ammonia from poultry farms. 
Russ, W., \& Meyer-Pittroff, R. (2004). Utilizing waste products from the food production and processing industries. Critical reviews in food science and nutrition, 44(1), 57-62.

Ryan, E and Gross, F. (1953), "The Adoption Process".Journal of cooperative extension. 1(2); Pp 130-131.

Subair, S.K.(1987), "Attitude of Farmers Towards Cultivation of Hybrid Variety of Cocoa in Ondo Local Government Area of Ondo State". Nigerian journal of Agronomy. 3 (1); Pp 47-53.

Ugwu, D. S. (2009). Baseline study of small and medium scale poultry production in Enugu and Lagos States of Nigeria. World Journal of Agricultural Sciences, 5(1), 27-33.

Verheijen, L.A.H.M., Wiersema, D. Hulshoff Pol, L.W. \& De Wit, J. (1996).Management of waste from animal product processing.Wageningen, the Netherlands, International Agricultural Centre. (available at http://www.fao.org/WAIRDOCS/LEAD/X61 14E/X6114E00.HTM)

Walker, P. (2000). Food residuals: Waste product, by-product, or co-product. Food Waste to
Animal Feed. M. L. Westendorf, ed. Iowa State University Press, Ames, IA.Pages 17-29.

Westendorf, M.L. (2000). Food waste to animal feed: An introduction. Food Waste to Animal Feed. M.L. Westendorf, ed. Iowa State University Press, Ames, IA.Pages 3-15.

Williams, S.K.T., Fenley J.M. and Williams, C.E. (1984), A Manual for Agricultural Extension Workers in Nigeria, S.T. Printers Rawalpindi, Pakistan, $169 \mathrm{pp}$

World Bank.(2007). Environmental, health, and safety guidelines for poultry production. Washington DC.

WHO.(2000). Air quality guidelines, second edition, Chapter 6.Hydrogen sulfide.www.euro.who.int/document/aiq/6_6h ydrogensulfide.pdf.Zublena, J. (1994). Excess soil levels of copper, zinc, and phosphorus dueto poultry manure applications. In: Proceedings 21st Annual Carolina Poultry Nutrition Conference, pp 17-25. Charlotte, North Carolina, USA, 7-8 Dec. 1994.P.R. Ferket, Ed. Carolina Feed Industry Association, Raleigh, NC - USA 27658. 
This page is intentionally left blank 